ORIGINAL ARTICLE

\title{
PENGARUH EKSTRAK DAUN PEPAYA (Carica papaya) TERHADAP KEMATIAN LARVA NYAMUK Aedes agypti INSTAR III
}

\author{
Jonathan Payangka ${ }^{1^{*}}$, Risma $^{2}$, Prajogo Wibowo ${ }^{3}$ \\ ${ }^{1}$ Program Studi Pendidikan Dokter, Fakultas Kedokteran Universitas Hang Tuah Surabaya, Indonesia \\ ${ }^{2}$ Departemen Parasitologi, Fakultas Kedokteran Universitas Hang Tuah Surabaya, Indonesia \\ ${ }^{3}$ Departemen Farmakologi, Fakultas Kedokteran Universitas Hang Tuah Surabaya, Indonesia \\ *Correspondent Author: Jonathan.payangka@yahoo.com
}

\section{ARTICLE INFO}

\section{Article history:}

Received 23 January 2019

Received in revised form

February 2019

Accepted 4 February 2019

\section{Keywords: \\ Carica papaya leaves, \\ Dengue fever, \\ Aedes aegypti}

\section{Kata Kunci:}

Daun Carica papaya,

Dengue fever,

Aedes aegypti

\begin{abstract}
Background: Papaya leaves (Carica papaya) extract is a natural larvacide that contains papain and alkaloid karpain so its usage is safe for the environment. The larvacide properties can also be used to reduce the amount of Aedes aegypti mosquito larvae. This mosquito species is the main vector for the virus that causes dengue fever which incident number increases over the years. There have been a few methods used to control the mosquito's amount, one of which is by decreasing the number of Aedes aegypti's larvae using the organophosphate insecticide chemical known as temefos. Temefos is really effective in killing the Aedes aegypti larvae but it has a lot of side effects especially towards the environment. By controlling the number of the Aedes aegypti's larvae, hopefully the number of the dengue fever case can also be reduced. Objective: To prove that the papaya leaves (Carica papaya) extract have effects on the death of Aedes aegypti's instar III larvae. Method: This is an experimental research what uses a post test only control group design. The study consists of seven groups, which are positive control that is given abate powder, negative control that is given only aquadest, and five groups treated with concentrations of $0.5 \%, 1 \%, 1.5 \%, 2 \%$, and $2.5 \%$; repeated for four times. The calculation of the amount of dead larvae is done within the first 24 hours. Result: Based on the Kruskal-Wallis test, p's value is $<\alpha$ with p value being 0.000 and $\alpha$ being 0.05 . It proves the significance of the experiment. Conclusion: The papaya leaves (Carica papaya) extract have effects on the death of Aedes aegypti's instar III larvae.
\end{abstract}

\begin{abstract}
ABSTRAK
Latar Belakang: Ekstrak daun papaya (Carica papaya) merupakan bahan larvasida alami yang mengandung papain dan alkaloid karpain sehingga penggunaannya aman bagi lingkungan. Sifat larvasidanya juga dapat diterapkan untuk mengurangi jumlah larva nyamuk Aedes aegypti. Nyamuk spesies ini adalah vektor utama untuk virus yang dapat menyebabkan demam dengue yang tingkat insidensinya semakin lama semakin meningkat. Sudah ada beberapa metode kontrol nyamuk yang dipakai, salah satunya adalah mengurangi jumlah larva nyamuk dengan menggunakan insektisida organofosfat kimiawi yang disebut sebagai temefos. Temefos sangat baik dalam membunuh larva nyamuk Aedes aegypti namun memiliki banyak efek samping terutama bagi lingkungan. Dengan mengontrol jumlah larva nyamuk ini diharapkan akan terjadi penurunan jumlah kasus demam dengue.Tujuan: Untuk membuktikan bahwa ekstrak daun pepaya (Carica papaya) dapat mempengaruhi kematian larva nyamuk Aedes aegypti instar III. Metode: Penelitian ini adalah penelitian eksperimental menggunakan post test only con-trol group design. Penelitian terdiri dari tujuh kelompok, yaitu kelompok kon-
\end{abstract}

Correspondence: Jonathan Payangka 
-trol positif yang diberi bubuk abate, kelompok kontrol negatif yang hanya diberi aquades dan lima kelompok perlakuan dengan konsentrasi 0,5\%, 1\%, $1,5 \%, 2 \%$, dan 2,5\%; diulang sebanyak empat kali. Penghitungan jumlah larva nyamuk yang mati dilakukan setelah 24 jam. Hasil: Berdasarkan uji KruskalWallis didapatkan $\mathrm{p}<\alpha$ dengan $\mathrm{p}=0,000$ dan $\alpha=0,05$. Hal ini membuktikan signifikansi penelitian. Kesimpulan: Ekstrak daun papaya (Carica papaya) dapat mempengaruhi kematian larva nyamuk Aedes aegypti instar III.

\section{PENDAHULUAN}

Carica papaya merupakan tanaman yang banyak dijual secara komersil dengan negaranegara produsen terbesarnya termasuk Indonesia, Brazil, Nigeria, Mexico, dan India. Tanaman ini mengandung banyak senyawa diantaranya ada vitamin $\mathrm{A}$, vitamin $\mathrm{C}$, kalsium, papain, dan lainlain (Encyclopedia of Life, 2018). Senyawasenyawa yang terkandung di daun papaya adayang bersifat larvasida yaitu papain dan alkaloid karpain (Shadana et al, 2014). Senyawa yang paling aktif pada Carica papaya merupakan papain (Wahyuni, 2014).

Papain merupakan enzim yang terdapat pada daun, getah pohon, akar, dan buah dari tanaman papaya yang mengkatalisasi proses pemecahan protein dengan menambahkan molekul air yang disebut sebagai hidrolisis (Encyclopedia Britannica, 2018). Untuk pertumbuhannya, larva nyamuk Aedes aegypti ini memerlukan senyawasenyawa protein layaknya lesitin dan karena adanya aktivitas proteolitik dari papain, pertumbuhanlarva tersebut menjadi terhambat (Tyas et al, 2014). Asetilkolin pada larva nyamuk berfungsi sebagai suatu neurotransmiter. Ketika senyawa tersebut sudah digunakan, maka akan dipecah oleh enzim asetilkolinasease menjadi asetil Ko-A dan kolin. Alkaloid karpain akan menghambat kerja enzim tersebut sehingga terjadi kejang, lumpuh, dan berujung pada kematian (Anwar et al, 2018).

Keunggulan dari ekstrak dari daun papaya sebagi larvasida adalah sifatnya yang ramah lingkungan sehingga dapat menggantikan bahan insektisida sintetis (Hayatie et al, 2015).
Penggunaan ekstrak tersebut sebagai bahan insektisida tidak memiliki efek buruk terhadap lingkungan dan manusia karena dapat didegradasi dengan mudah sehingga tidak meninggalkan residu baik pada tanah, air, dan udara (Yunair et al, 2017).

Aedes aegypti adalah vector nyamuk utama untuk virus dengue dan nyamuk ini adalah suatu serangga yang sangat erat kaitannya dengan manusia dan segala kegitannya (CDC, 2017). Pola transmisi dari virus degue ini sangat dipengaruhi oleh jumlah, tingkat kelangsungan hidup, dan tingkah laku Aedes aegypti itu sendiri; level imunitas terhadap serotype virus pada populasi manusia local; kepadatan, distribusi, pergerakan manusia; dan waktu yang diperlukan untuk perkembangan virus di Ae. aegypti, walaupun belum sepenuhnya dipahami hubungan satu faktor dengan yang lain termasuk bagaimana mereka bervariasi dari suatu tempat ke tempat lain dan suatu waktu ke waktu yang lain (Getis et al,2010). Penyebaran dari nyamuk ini apabila dikontrol maka akan dapat mengurangi penyebaran penyakit demam dengue itu sendiri. Kontrol terhadap penyebaran nyamuk Ae. aegypti ini dapat dilakukan dengan beberapa prinsip yaitu : menghilangkan habitat larvanya untuk mengurangi sumber, mengkontrol perkembangan larvanya menggunakan bahan-bahan yang bersifat larvasida, mengkontrol nyamuk dewasanya, memonitor resistensi pestisida dan mencegah transmisinya (CDC, 2016). Untuk kontrol nyamuk pada tahap larva ini bisa menggunakan beberapa cara : insektisida bakterial, penghambat pertumbuhan serangga, insektisida organofosfat, dan bahan- 
bahan lain (EPA, 2018). Salah satu cara yang direkomendasikan oleh WHO adalah dengan menggunakan pestisida organofosfat yang disebut temefos (WHO, 2017). Cara kerja senyawa ini adalah dengan sistem saraf serangga (EPA, 2018). Dia dapat menjadi efektif ketika terjadi kontak dengan larva tersebut (Kemabonta \& Nwanko, 2013). Temefos juga memiliki nama kimiawi lain seperti difos, biothion, dan abate (Pubchem, 2018). Kekurangan dari penggunaan temefos adalah efek sampingnya pada lingkungan yang mana senyawa tersebut bersifat sangat toksik terhadap organisme aquatic dan dapat menimbulkan efek samping yang berkepanjangan terhadap lingkungan aquatic (BASF, 2012).

Demam dengue ditransmisikan oleh gigitan nyamuk Aedes aegypti, yang terinfeksi oleh salah satu dari empat macam virus dengue. Penyakit demam dengue biasanya terjadi di daerah tropis dan sub-tropis di dunia (WHO, 2017). Dengue fever atau yang dalam Bahasa Indonesia dikenal dengan demam dengue adalah suatu penyakit yang penyebaran resiko infeksinya dan beban kesehatannya dalam masyarakat di seluruh dunia masih kurang diketahui (Bahtt et al, 2013).

Penyakit demam dengue sendiri beberapa dekade belakangan ini telah meningkat pesat tingkat insidensinya (WHO, 2017). Walaupun terdapat penyakit yang tercatat di Tiongkok pada sekitar tahun 900 dengan gejala yang mirip dengan demam dengue, hal ini tidak berarti penyakit demam dengue pasti berasal dari Negara tersebut (Halstead, 2016). Diperkirakan juga bahwa dengue berasal dari Afrika, bersamaan dengan yellow fever, tersebar ke new world pada tahun 1600-an (Farrar et al, 2009). Yang diketahui secara pasti adalah bahwa terdapat epidemi penyakit dengan gejala yang mirip demam dengue pertama kali dilaporkan pada tahun 1635 di Martinique (Dick, 2012). Di dunia diperkirakan 2,5 milliar orang beresiko terinfeksi, dan sekitar 975 jutanya adalah orang-orang yang tinggal di daerah perkotaan di negara tropis dan sub-tropis di Asia Tenggara, daerah Pasifik, dan benua Amerika (Guzman et al, 2010). Di Asia Tenggara sendiri, dari tahun 2001 hingga 2010 ada 386.154 kasus demam dengue yang tercatat dimana sebagian besar kasus ini terjadi di Indonesia, yaitu 104.457 kasus dengan 1.041 kasus diantaranya bersifat fatal. Di bawah Indonesia ada Thailand dengan jumlah kasus 76.978 yang mana angka ini masih jauh jika dibandingkan dengan kasus yang terjadi di Indonesia sendiri (Shepard et al, 2013). Surabaya, yang merupakan kota terbesar ke-2 di Indonesia dan ibukota dari provinsi Jawa Timur, memiliki insidensi tahunan dari kasus demam dengue sebanyak 2.000 - 3.000 dan terkait dengan 10 kematian selama tahun 2002 - 2012 (Mulyatno et $a l, 2012)$. Gejala dari demam dengue sendiri akan muncul sekitar tiga hingga empat belas hari setelah gigitan nyamuk (WHO,2017).

Penelitian serupa sebelumnya pernah dilakukan; salah satunya adalah penelitian dengan judul "Uji Potensi Ekstrak Daun Pepaya (Carica papaya L.) Sebagai Larvasida Terhadap Larva Aedes aegypti instar III" yang dilaksanakan di Lampung, Indonesia terhadap populasi nyamuk setempat (Saraswati et al, 2014). Hasil penelitiannya menunjukkan adanya efek larvasida yang cukup signifikan akibat adanya senyawa aktif sebagai kandungan ekstrak yang dipakai (Saraswati et al, 2014 dan Hayatie et al, 2015). Berdasarkan latar belakang di atas, maka peneliti ingin mengetahui pengaruh ekstrak daun papaya (Carica papaya) terhadap perkembangan larva nyamuk Aedes aegypti yang terdapat di Surabaya.

\section{METODE PENELITIAN}

Penelitian ini merupakan penelitian eksperimental laboratoris yang tidak memperhitungkan faktor luar (suhu, cuaca, dan $\mathrm{pH}$ ) dan bertujuan untuk mengetahuipengaruh pemberian ekstrak daun papaya (Carica papaya) 
yang dapat membunuh larva nyamuk Aedes aegypti instar III.

Metode penelitian yang digunakan adalah post test only control groupdesign karena pengukuran hanya dilakukan satu kali, yaitu setelah larva nyamuk Aedes aegypti instar III diberi ekstrak daun papaya (Carica papaya).

Dalam penelitian ini terdapat 7 perlakuan (5 perlakuan +1 kontrol negatif +1 kontrol positif ) dan 4 kali pengulanggan. Setiap perlakuan pengulangan membutuhkan 25 ekor larva. Sehingga jumlah total larva nyamuk Aedes aegypti yang dibutuhkan dalam penelitian ini adalah 25 ekor $\mathrm{x} 7$ perlakuan $\mathrm{x} 4$ kali pengulangan $=700$ larvadengan skema:

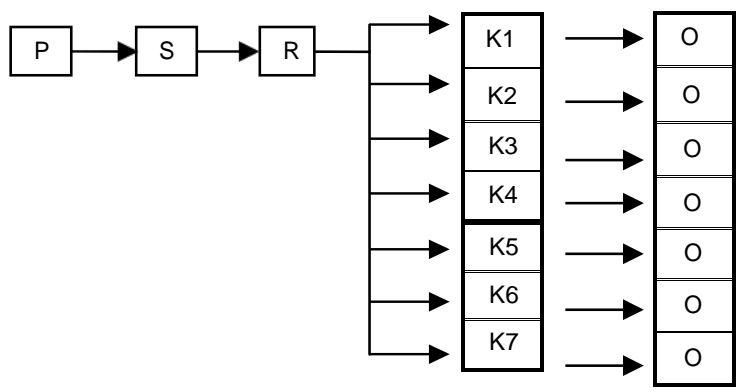

Keterangan :

P : Populasi

S : Sampel

$\mathrm{R} \quad$ : Randomisasi

K1 : Kelompok 1 perlakuan dengan konsentrasi ekstrak daun papaya (Carica papaya) $0,5 \%$

K2 : Kelompok 2 perlakuan dengan konsentrasi ekstrak daun papaya (Carica papaya) $1 \%$

K3 : Kelompok 3 perlakuan dengan konsentrasi ekstrak daun papaya (Carica papaya) 1,5\%

K4 : Kelompok 4 perlakuan dengan konsentrasi ekstrak daun papaya (Carica papaya) $2 \%$

K5 : Kelompok 5 perlakuan dengan konsentrasi ekstrak daun papaya (Carica papaya) 2,5\%

K6 : Kelompok 6 sebagai kontrol negatif (perlakuan dengan aquades saja)

K7 : Kelompok 7 sebagai kontrol positif (perlakuan dengan aquades yang dicampur abate)

O : Obeservasi jumlah larva Aedes aegypti yang mati setelah 24 jam
Populasi yang dipakai pada penelitian ini adalah larva nyamuk Aedes aegypti instar III yang di dapat dari Laboratorium Entomologi Dinas Kesehatan Jawa Timur di Surabaya.

Sampel yang akan di gunakan pada penelitian ini adalah 25 ekor larva uji pada masing masing kelompok percobaan dan replikasinya.

a) Kriteria inklusi sampel

1) Larva Aedes Aegypti Instar IIIdidapatkan di Laboratorium Entomologi Dinas Kesehatan Jawa Timur di Surabaya.

2) Larva hidup masih bergerak aktif.

b) Kriteria eksklusi sampel

1) Larva Aedes aegypti yang belum mencapai instar III atau sudah mencapai IV

2) Larva Aedes aegypti yang telah berubah menjadi pupa atau dewasa

3) Larva Aedes aegypti yang tidak bergerak aktif (mati) sebelum perlakuan

Pengambilan sampel pada larva Aedes aegypti dilakukan secara Simple Random Sampling (SRS) yaitu setiap sampel memiliki kesempatan yang sama untuk dipilih sebagai sampel kelompok kontrol ataupun kelompok perlakuan.

Ekstrak daun papaya (Carica papaya)dibuat dengan metode maserasi, yaitu dengan cara dipanaskan, dikeringkan, lalu dihalus kan dan dicampur dengan alkohol, kemudian disaring dan terakhir diuapkan.

Tahap pengujian ekstrak daun papaya sesuai konsentrasi yang sudah di tentukan yaitu $0,5 \%, 1 \%$, $1,5 \%, 2 \%$ dan 2,5\%. Ekstrak daun papaya (Carica papaya) lalu diambil dengan pipet dan dimasukkan ke dalam gelas percobaan sesuai volume yang dibutuhkan agar sesuai konsentrasi yang diperlukan dengan mengunakan rumus.

Data yang dikumpulkan adalah dengan cara menghitung jumlah larva yang mati pada setiap kelompok , Penghitungan larva yang mati dilakukan setelah kurun waktu 24 jam, kemudian di catat dalam bentuk tabel. Larva yang mati merupakan larva yang tenggelam ke dasar wadah, tidak bergerak, meninggalkan larva yang lain yang dapat bergerak dengan jelas dan tidak berespon terhadap rangsangan (Ashry AS ,2009). 
Larva juga tetap tidak bergerak setelah disentuh dengan jarum atau lidi pada bagian siphon atau cervical.larva yang hampir mati adalah larva yang tidak dapat naik ke permukaan air dan tidak menyelam kedasar permukaan air meskipun air digoyangkan atau di gerakkan (WHO,2005).

Penyajian data secara deskriptif disajikan dalam bentuk tabel secara analitik. Perhitungan persentase kematian larva menggunakan rumus:

$$
\text { Mortalitas }(\%)=\frac{\text { Kematian Larva }}{25} \times 100 \%
$$

Cara analisis data pada peneliian ini menggunakan program SPSS 23,0. Apabila hasil uji normalitas berdistribusi normal dan varian homogen akan dilakukan uji parametrik, bila data tidak berdistribusi normal makan dilakukan analissi data dengan uji nonparametrik.

\section{HASIL PENELITIAN}

Penelitian ini merupakan penelitian eksperimental laboratorium dengan rancangan penelitian post test only controlled group design. Penelitian ini dilakukan untuk mengetahui pengaruh ekstrak daun papaya (Carica papaya) dalam konsentrasi yang berbeda terhadap jumlah kematian lerva nyamuk Aedes aegypti instar III. Masing-masing konsentrasi tersebut dibandingkan dengan kontrol negatif yang berisi air saja dan kontrol positif yang berisi temefos.

Penelitian ini menggunakan 7 wadah yang masing-masing berisi 25 ekor larva nyamuk Aedes aegypti instar III yang terbagi dalam kontrol positif, kontrol negatif, serta kelompok perlakuan yaitu ekstrak daun papaya (Carica papaya) dengan konsentrasi $0,5 \%, 1 \%, 1,5 \%, 2 \%$, dan 2,5\%. Pada penelitian ini dilakukan replikasi atau pengulangan sebanyak 4 kali sesuai dengan perhitungan uji replikasi.

\section{Data Jumlah Kematian Larva Nyamuk Aedes aegypti instar III}

Hasil pengamatan mengenai jumlah kematian larva dapat dilihat pada tabel berikut:

Tabel 1. Jumlah kematian larva nyamuk Aedes aegypti

\begin{tabular}{|l|l|l|l|l|l|l|}
\hline $\begin{array}{c}\text { No } \\
.\end{array}$ & Konsentrasi & $\mathrm{R} 1$ & $\mathrm{R} 2$ & $\mathrm{R} 3$ & $\mathrm{R} 4$ & Rata-rata \\
\hline 1. & Kontrol (+) & 25 & 25 & 25 & 25 & 25 \\
\hline 2. & $\begin{array}{l}\text { Kontrol (-) } \\
0 \%\end{array}$ & 0 & 0 & 0 & 0 & 0 \\
\hline 3. & $0,5 \%$ & 2 & 1 & 0 & 1 & 1 \\
\hline 4. & $1 \%$ & 5 & 3 & 0 & 1 & 2,25 \\
\hline 5. & $1,5 \%$ & 5 & 4 & 6 & 9 & 6 \\
\hline 6. & $2 \%$ & 12 & 16 & 13 & 15 & 14 \\
\hline 7. & $2,5 \%$ & 21 & 20 & 21 & 23 & 21,25 \\
\hline
\end{tabular}

Keterangan :

$\begin{array}{ll}\text { R1 } & \text { : Pengulangan pertama } \\ \text { R2 } & \text { : Pengulangan kedua } \\ \text { R3 } & \text { : Pengulangan ketiga } \\ \text { R4 } & \text { : Pengulangan keempat } \\ \text { Konsentrasi } & \begin{array}{l}\text { : Jumlah konsentrasi pemberian larutan ektrak daun } \\ \text { papaya }\end{array} \\ \text { Rata-rata } & \begin{array}{l}\text { : Jumlah rata-rata kematian larva dari empat } \\ \text { pengulangan }\end{array} \\ \text { Catatan } & \text { : Setiap perlakuan menggunakan 25 larva } \\ & \text { nyamuk Aedes aegypti instar III tanpa diberi } \\ & \text { makan waktu uji. }\end{array}$

Tabel 1 di atas menunjukkan bahwa angka rata-rata kematian terkecil, 1 larva, ada pada konsentrasi terendah yaitu $0,5 \%$ dan angka rata-rata kematian terbesar, 21,25 larva, ada pada konsentrasi terbesar yaitu 2,5\%. Ini artinya peningkatan rata-rata jumlah kematian sebanding dengan peningkatan konsentrasi.

\section{Data Persentase Kematian Larva Nyamuk Aedes aegypti instar III}

Hasil pengamatan mengenai jumlah kematian larva dapat dilihat pada tabel berikut:

Tabel 2. Persentase kematian larva nyamuk Aedes

\begin{tabular}{|l|l|l|l|l|l|l|}
\hline $\begin{array}{c}\text { No } \\
.\end{array}$ & Konsentrasi & $\begin{array}{l}\mathrm{R} 1 \\
(\% \\
)\end{array}$ & $\begin{array}{l}\mathrm{R} 2 \\
(\% \\
)\end{array}$ & $\begin{array}{l}\mathrm{R} 3 \\
(\% \\
)\end{array}$ & $\begin{array}{l}\mathrm{R} 4 \\
(\% \\
)\end{array}$ & $\begin{array}{l}\text { Rata } \\
\text { rata } \\
(\%)\end{array}$ \\
\hline 1. & Kontrol (+) & 100 & 100 & 100 & 100 & 100 \\
\hline 2. & $\begin{array}{l}\text { Kontrol (-) } \\
0 \%\end{array}$ & 0 & 0 & 0 & 0 & 0 \\
\hline 3. & $0,5 \%$ & 8 & 4 & 0 & 4 & 4 \\
\hline 4. & $1 \%$ & 20 & 12 & 0 & 4 & 9 \\
\hline 5. & $1,5 \%$ & 20 & 16 & 24 & 36 & 24 \\
\hline 6. & $2 \%$ & 48 & 64 & 52 & 60 & 56 \\
\hline 7. & $2,5 \%$ & 84 & 80 & 84 & 92 & 85 \\
\hline
\end{tabular}


Keterangan :

$\begin{array}{ll}\text { R1 } & \text { : Pengulangan pertama } \\ \text { R2 } & \text { : Pengulangan kedua } \\ \text { R3 } & \text { : Pengulangan ketiga } \\ \text { R4 } & \text { : Pengulangan keempat } \\ \text { Konsentrasi } & \text { : Jumlah konsentrasi pemberian larutan } \\ & \text { ektrak daun papaya } \\ \text { Rata-rata } & \text { : Persentase rata-rata kematian larva dari } \\ & \text { empat pengulangan } \\ \text { Catatan } & \text { : Setiap perlakuan menggunakan 25 larva } \\ & \text { nyamuk Aedes aegypti instar III tanpa } \\ & \text { diberi makan waktu uji. }\end{array}$

Tabel 2 di atas menunjukkan bahwarata-rata persentase kematian terkecil, 4\%, ada pada konsentrasi terendah yaitu $0,5 \%$ dan rata-rata persentase kematian terbesar, $85 \%$, ada pada konsentrasi terbesar yaitu 2,5\%. Hasil ini menunjukkan bahwa peningkatan rata-rata persentase kematian sebanding dengan peningkatan konsentrasi.

\section{Hasil Analisa Statistika}

Analisa data penelitian ini menggunakan SPSS 23.0 untuk mempermudah pengolahan data.

\section{Analisis Uji Normalitas}

Hipotesis :

- $\quad$ H0 : Data terdistribusi dengan normal.

- $\quad$ H1 : Data tidak terdistribusi dengan normal.

Tabel 3. Hasil Uji Normalitas

\begin{tabular}{|l|l|}
\hline Shapiro-Wilk \\
\hline $\begin{array}{l}\text { Kematian Larva } \\
\text { (Sig.) }\end{array}$ & 0,001 \\
\hline
\end{tabular}

Hasil uji normalitas dengan metode uji Shapiro-Wilk menunjukan nilai signifikansi (Sig.) kurang dari $\alpha(0,05)$ yang berarti distribusi data tidak normal. Dari hasil uji normalitas, dapat disimpulkan bahwa langkah selanjutnya adalah analisis data, tanpa melalui uji homogenitas, karena data diatas tidak memenuhi syarat uji analisis Oneway ANOVA sehingga harus digunakan metode Kruskal-Wallis untuk menganalisis data.

\section{Uji Kruskall-Wallis}

\section{Data Jumlah Kematian Larva Nyamuk Aedes aegypti Instar III}

Hipotesis :

- H0 : Tidak ada perbedaan rerata kematian larva nyamuk Aedes aegypti antar kelompok berdasarkan konsentrasi ekstrak daun papaya (Carica papaya).

- H1 : Ada perbedaan rerata kematian larva nyamuk Aedes aegypti antar kelompok berdasarkan konsentrasi ekstrak daun papaya (Carica papaya).

Tabel 4. Hasil Uji Kruskall-Wallis Data Jumlah Kematian Larva Nyamuk Aedesaegypti Instar III

\begin{tabular}{|l|l|l|l|l|l|l|l|}
\hline $\begin{array}{c}\text { No } \\
\text {. Konsentrasi }\end{array}$ & R1 & R2 & R3 & R4 & $\begin{array}{l}\text { Rata } \\
\text { rata }\end{array}$ & $\begin{array}{l}\text { Rata } \\
\text { rata } \\
(\%)\end{array}$ \\
\hline 1. & Kontrol (+) & 25 & 25 & 25 & 25 & 25 & 100 \\
\hline 2. & $\begin{array}{l}\text { Kontrol (-) } \\
0 \%\end{array}$ & 0 & 0 & 0 & 0 & 0 & 0 \\
\hline 3. & $0,5 \%$ & 2 & 1 & 0 & 1 & 1 & 4 \\
\hline 4. & $1 \%$ & 5 & 3 & 0 & 1 & 2,25 & 9 \\
\hline 5. & $1,5 \%$ & 5 & 4 & 6 & 9 & 6 & 24 \\
\hline 6. & $2 \%$ & 12 & 16 & 13 & 15 & 14 & 56 \\
\hline 7. & $2,5 \%$ & 21 & 20 & 21 & 23 & 21,25 & 85 \\
\hline$p=0,000(p<0,05)$
\end{tabular}

Berdasarkan hasil analisis Kruskall-Wallis yang tercantum pada tabel 5.4, didapatkan bahwa nilai signifikansi (Asymp. Sig.) lebih kecil dari 0,05 ( $\mathrm{p}<0,05)$. Dari hasil tersebut dapat disimpulkan bahwa terdapat perbedaan jumlah kematian larva nyamuk Aedes aegypti pada masing-masing perlakuan, maka uji yang harus dilaksanakan selanjutnya adalah uji Mann-Whitney U untuk melihat letak perbedaannya.

\section{Uji Mann-Whitney $\mathrm{U}$}

\section{Hipotesis :}

- H0 : Tidak ada perbedaan rerata kematian larva nyamuk Aedes aegypti antara dua konsentrasi yang dibandingkan.

- H1 : Ada perbedaan rerata kematian larva nyamuk Aedes aegypti antara dua konsentrasi yang dibandingkan. 
Tabel 5. Hasil Uji Mann-Whitney U Data Jumlah Kematian Larva Nyamuk Aedesaegypti Instar III

\begin{tabular}{|l|l|l|l|l|l|l|l|}
\hline $\begin{array}{l}\text { Konsentr } \\
\text { asi }\end{array}$ & $0 \%$ & $\begin{array}{l}0,5 \\
\%\end{array}$ & $1 \%$ & $\begin{array}{l}1,5 \\
\%\end{array}$ & $2 \%$ & $\begin{array}{l}2,5 \\
\%\end{array}$ & $\begin{array}{l}\text { Kontrol } \\
(+)\end{array}$ \\
\hline $0 \%$ & - & & & & & & \\
\hline $0,5 \%$ & $\begin{array}{l}0,04 \\
6\end{array}$ & - & & & & & \\
\hline $1 \%$ & $\begin{array}{l}0,04 \\
7\end{array}$ & 0,45 & - & & & & \\
\hline $1,5 \%$ & $\begin{array}{l}0,01 \\
4\end{array}$ & $\begin{array}{l}0,02 \\
0\end{array}$ & 0,05 & - & & & \\
\hline $2 \%$ & $\begin{array}{l}0,01 \\
4\end{array}$ & $\begin{array}{l}0,02 \\
0\end{array}$ & $\begin{array}{l}0,02 \\
1\end{array}$ & $\begin{array}{l}0,02 \\
1\end{array}$ & - & & \\
\hline $2,5 \%$ & $\begin{array}{l}0,01 \\
3\end{array}$ & $\begin{array}{l}0,01 \\
9\end{array}$ & $\begin{array}{l}0,02 \\
0\end{array}$ & $\begin{array}{l}0,02 \\
0\end{array}$ & $\begin{array}{l}0,02 \\
0\end{array}$ & - & \\
\hline $\begin{array}{l}\text { Kontrol } \\
(+)\end{array}$ & $\begin{array}{l}0,00 \\
8\end{array}$ & $\begin{array}{l}0,01 \\
3\end{array}$ & $\begin{array}{l}0,01 \\
4\end{array}$ & $\begin{array}{l}0,01 \\
4\end{array}$ & $\begin{array}{l}0,01 \\
4\end{array}$ & $\begin{array}{l}0,01 \\
3\end{array}$ & - \\
\hline
\end{tabular}

Keterangan :

: Berbeda secara signifikan $(\mathrm{p}<0,05)$

: Tidak berbeda secara signifikan ( $\mathrm{p}>$ 0,05) Penjelasan tabel 5 :

1. Kelompok kontrol (-) atau $0 \%$ terdapat perbedaan rerata jumlah kematian larva nyamuk Aedes aegypti dengan ekstrak daun papaya (Carica papaya) yaitu pada konsentrasi $0,5 \%, 1 \%, 1,5 \%, 2 \%$, dan $2,5 \%$, dan juga dengan kontrol (+) karena memiliki nilai $\mathrm{p}<0,05$.

2. Konsentrasi $0,5 \%$ tidak terdapat perbedaan rerata jumlah kematian larva nyamuk Aedes aegypti dengan konsentrasi $1 \%$ karena $\mathrm{p}>0,05$ namun terdapat perbedaan rerata jumlah kematian larva nyamuk Aedes aegypti dengan konsentrasi 1,5\%, $2 \%$, dan 2,5\%, dan juga dengan kontrol(+) karena memiliki nilai $\mathrm{p}<0,05$.

3. Konsentrasi $1 \%$ tidak terdapat perbedaan rerata jumlah kematian larva nyamuk Aedes aegypti dengan konsentrasi 1,5\% karena $\mathrm{p}>0,05$ namun terdapat perbedaan rerata jumlah kematian larva nyamuk Aedes aegypti dengan konsentrasi 2\%, dan $2,5 \%$, dan juga dengan kontrol (+) karena memiliki nilai $\mathrm{p}<0,05$.

4. Konsentrasi $1,5 \%$ terdapat perbedaan rerata jumlah kematian larva nyamuk Aedes aegypti dengan konsentrasi $2 \%$ dan $2,5 \%$ serta kontrol (+) karena memiliki nilai $\mathrm{p}<0,05$.
5. Konsentrasi $2 \%$ terdapat perbedaan rerata jumlah kematian larva nyamuk Aedes aegypti dengan konsentrasi $2,5 \%$ dan kontrol (+) karena memiliki nilai $\mathrm{p}<0,05$.

6. Konsentrasi $2,5 \%$ terdapat perbedaan rerata jumlah kematian larva nyamuk Aedes aegypti dengan kontrol (+) karena memiliki nilai $\mathrm{p}<0,05$.

\section{DISKUSI}

Hasil penelitian ini menunjukkan bahwa ekstrak daun pepaya (Carica papaya) pada beberapa konsentrasi berpengaruh terhadap kematian larva Aedes aegypti instar III dengan pengaruh terendah pada dosis $0,5 \%$ yaitu $4 \%$ dan paling tinggi pada $2,5 \%$ yaitu $85 \%$. Peningkatan persentase kematian ini menunjukkan kenaikan yang sebanding dengan peningkatan persentase konsentrasi.

Untuk memudahkan peneliti dalam melakukan analisis data digunakan program SPSS 23.0. Analisis yang dilakukan diawali dengan uji normalitas menggunakan metode KolmogorovSmirnov untuk melihat apakah data sudah terdistribusi secara normal atau belum. Uji normalitas menunjukkan bahwa data tidak terdistribusi secara normal sehingga peneliti langsung melakukan uji Kruskal-Wallis tanpa melaui uji homogenitas.

Uji Kruskal-Wallis, sesuai dengan tabel 5.4, memberikan hasil nilai signifikansi atau nilai $\mathrm{p}$ (Asymp. Sig.) sebesar 0,000 yang berarti $\mathrm{p}<0,05$ atau $\mathrm{p}$ signifikan. Nilai $\mathrm{p}$ yang signifikan ini menunjukkan bahwa ekstrak daun pepaya (Carica papaya) memiliki pengaruh terhadap kematian larva nyamuk Aedes aegypti. Uji Kruskal-Wallis harus diikuti dengan uji post hoc multiple comparisons yaitu uji post hocMann-Whitney $U$ untuk melihat perbedaan rerata jumlah kematian larva nyamuk Aedes aegypti instar III dari masingmasing kelompok.

Hasil uji Mann-Whitney $U$ yang tertera pada tabel 5.5 menunjukkan bahwa perbedaan yang signifikan dari rerata jumlah kematian larva nyamuk Aedes aegypti instar III didapati pada semua kelompok kecuali antara kelompok dengan 
dosis ekstrak daun pepaya (Carica papaya) sebesar $0,5 \%$ dengan $1 \%$ dan antara kelompok dengan dosis ekstrak daun pepaya (Carica papaya) sebesar $1 \%$ dengan $1,5 \%$.

Pada penelitian ini secara teori kandungan daun pepaya (Carica papaya) memiliki dua kandungan aktif yang dapat menyebabkan larva mati. Kandungan aktif pertama yang bersifat larvasida dalam daun pepaya (Carica papaya) adalah papain (Adachukwu et al, 2013). Papain dapat digunakan sebagai larvasida karena bersifat proteolitik sehingga dapat memecah protein lesitin yang dibutuhkan larva untuk berkembang (Tyas $e t$ $a l$, 2014). Kandungan aktif kedua yang bersifat larvasida dalam daun pepaya (Carica papaya) adalah alkaloid karpain (Shadana et al, 2014). Kerja alkaloid karpain sebagai larvasida adalah dengan menghambat kerja dari enzim asetilkolinasease yang memecah neurotransmiter asetilkolin menjadi asetil Ko-A dan kolin sehingga larva kejang, lumpuh, atau bahkan mati (Anwar et al, 2018).

Penelitian serupa sebelumnya juga pernah dilakukan di Lampung dengan judul "Uji Potensi Ekstrak Daun Pepaya (Carica papaya L.) Sebagai Larvasida Terhadap Larva Aedes aegypti instar III." Hasil penelitian tersebut juga menunjukkan hasil yang signifikan bahkan dalam dosis yang lebih kecil. Dosis terkecil yang dapat menimbulkan pengaruh pada kematian larva nyamuk pada penelitian tersebut adalah sebesar $0,2 \%$ dengan rata-rata kematian $6,25 \%$ dan yang terbesar pada dosis $1 \%$ dengan rata-rata kematian $60 \%$ (Saraswati et al, 2014). Dari perbandingan kedua penelitian ini peneliti menyimpulkan bahwa dalam penelitian tipe ini dapat terjadi perbedaan hasil penelitian. Hal-hal yang dapat mempengaruhi hasil penelitian yang dimaksud antara lain adalah persentase kandungan yang berbeda karena sumber daun berbeda dan efek pada larva berbeda karena larva tidak dari tempat yang sama.

Statistik hasil penelitian menunjukkan angka kematian larva nyamuk Aedes aegypti instar III tidak terdistribusi secara normal dan didapatkan adanya perbedaan jumlah rerata kematian larva nyamuk Aedes aegypti instar III pada hampir semua kelompok kecuali antara kelompok dengan dosis ekstrak daun pepaya (Carica papaya) $0,5 \%, 1 \%$, dan $1,5 \%$. Hasil angka kematian larva tertinggi didapatkan pada kelompok dengan dosis ekstrak daun pepaya (Carica papaya) $2,5 \%$.

\section{KESIMPULAN}

Dari pembahasan pada bab sebelumnya, peneliti menyimpulkan bahwa penggunaan ekstrak daun pepaya (Carica papaya) sebagai larvasida nyamuk Aedes aegypti akan mempengaruhi jumlah kematian larva instar III-nya karena sejumlah larva didapati mati setelah 24 jam pemberian ekstrak daun pepaya (Carica papaya).

Ada perbedaan rerata jumlah kematian larva tersebut pada hampir seluruh kelompok kecuali antara kelompok dengan dosis ekstrak daun pepaya (Carica papaya) $0,5 \%$ dengan $1 \%$ dan $1 \%$ dengan $1,5 \%$.

Penelitian ini juga menunjukkan bahwa angka kematian terendah pada konsentrasi 0,5\% (konsentrasi terendah) dan angka kematian tertinggi pada konsentrasi 2,5\% (konsentrasi tertinggi). Hal tersebut menunjukkan bahwa peningkatan jumlah kematian larva sebanding dengan peningkatan konsentrasi ekstrak daun papaya (Carica papaya).

\section{SARAN}

Perlu dilakukan penelitian lebih lanjut mengenai pengaruh ekstrak daun pepaya (Carica papaya) terhadap larva nyamuk Aedes aegypti instar III dengan konsentrasi yang lebih tinggi, terhadap kematian nyamuk Aedes aegypti dewasa, serta terhadap jenis nyamuk lain seperti Culex sp., dll.

\section{DAFTAR PUSTAKA}

1. Ayoola, P.B. \& Adeyeye, A. (2010). Phytochemical and Nutrient Evaluation of Carica papaya (Pawpaw) Leaves. Ladoke Akintola University of Technology, 5(3), 325328.

2. Bhatt, S., Gething, P. W., Brady, O. J., Messina, J. P., Farlow, A. W., Moyes, C. L., ... Hay, S. 
I. (2013). The global distribution and burden of dengue. Letter Research, 496, 504-507.

3. Britannica, T. E. of E. (2018, January 1). Papain. Retrieved February 5, 2018, from https://www.britannica.com/science/papain

4. Burdick, E. M. (1971). Carpaine: An alkaloid of Carica papaya-its chemistry and pharmacology. Economic Botany, 25(4), 363365.

5. Controlling Mosquitoes at the Larval Stage. (2016, November 18). Retrieved December 2, 2017 , from https://www.epa.gov/mosquitocontrol/controlli ng-mosquitoes-larval-stage

6. Dengue. (2017, May 31). Retrieved December 2, 2017, from. https://www.cdc.gov/dengue/entomologyecolo gy/index.html

7. Dengue and severe dengue. Retrieved December 2, 2017, from. http://www.who.int/mediacentre/factsheets/fs1 $\underline{17 / \mathrm{en} /}$

8. Depkes RI. 1986. Sediaan Galenik. Departemen Kesehatan RI. Jakarta.

9. Dick, O.B., Martin, J.L.S., Montoya, R.H., Diego, J.D., Zambrano, B., \& Dayan, G.H. (2012). Review : The History of Dengue Outebreaks in the Americas. The America Society of Tropical Medicine and Hygiene, 87(4), 584-593.

10. Farrar, J. (2014). Manson's tropical diseases. Philadelphia: Elsevier/Saunders.

11. Fatma, S. U. 2010. Identifikasi Vektor Malaria pada Daerah Pantai di Desa Hanura Padang Cermin Lampung Selatan. Skripsi. Fakultas Matematika dan Ilmu Pengetahuan Alam Universitas Lampung

12. Febriyanto, Anwar, C., Dalilah, Salni, \& Novrikasari. (2017). PAPAYA LEAF (Carica papaya L.) FRACTION EFFECTIVE AS BIOINSECTISIDE AGAINST Anopheles species (Diptera: Culicidae) LARVA INVITRO STUDY. Bioscientia Medicina, 2(1), 1-11.

13.13.

14. Getis, A., Morrison, A. C., Gray, K., \& Scott, T. W. (2008). Characteristics of the Spatial Pattern of the Dengue Vector, Aedes aegypti, in Iquitos, Peru. Perspectives on Spatial Data Analysis Advances in Spatial Science, 203-225.
15. Guzman, M. G., Halstead, S. B., Artsob, H., Buchy, P., Farrar, J., Gubler, D. J., ... Peeling, R. W. (2010). Dengue: a continuing global threat. Nature Reviews Microbiology, 8(12).

16. Halstead, S. B. (2008). Dengue: Overview and History. Dengue Tropical Medicine: Science and Practice, 1-28.

17. Hayatie, L., Biworo, A., \& Suhartono, E. (2015). Aqueous Extracts of Seed and Peel of Carica Papaya Against Aedes Aegypti. Journal of Medical and Bioengineering, 4(5), 417-421.

18. Kemabonta, K. A., \& Nwankwo. A. E. (2013). Larvacidal Effectiveness Of Spinosad and Temephos On Anopheles gambiae \& Aedes aegypti. Larvacidal Effectiveness Of Spinosad and Temephos On Anopheles Gambiae \& Aedes Aegypti, 4(2), 214-222.

19. Ming, R., \& Moore, P. H. (2014). Genetics and Genomics of Papaya. New York, NY: Springer.

20. Mulyatno, K. C., Yamanaka, A., Yotopranoto, S., \& Konishi, E. (2012). Vertical Transmission of Dengue Virus in Aedes aegypti Collected in Surabaya, Indonesia, during 20082011. Japanese Journal of Infectious Diseases, 65(3), 274-276.

21. Papain. Retrieved April 10, 2018, from https://www.drugbank.ca/drugs/DB11193

22. Papain. Retrieved April 11, 2018, from https://pubchem.ncbi.nlm.nih.gov/compound/p apain\#section=2D-Structure

23. Papaya - Carica papaya - Details. Retrieved December 10, 2017, from http://eol.org/pages/585682/details

24. Pauline, I.A., Ogbonna, A., \& Faith, E. (2013). Phytochemical Analysis of Paw-paw (Carica papaya) Leaves. International Journal of Life Sciences Biotechnology and Pharma Research, 2(3), 346-352.

25. Ramadhan, M.R.F., 2016. Toksisitas Campuran Ekstrak Biji Pepaya (Carica papaya L.) dan Biji Srikaya (Annona squmosa L.) terhadap Mortalitas Larva Nyamuk Aedes aegypti L. Jember.

26. Regulator, Gene Technology. 2008. The Biology of Carica papaya L . ( papaya, papaw , paw paw ).

27. Rothman, A. L. (2013). Dengue Virus. Berlin: Springer Berlin.

28. Service, M. W. (2012). Medical Entomology for Students. Cambridge: Cambridge University Press. 
29. Shadana, M., Lesmana, S.D., \& Hamidy, M.Y. (2014). Efek Larvasida Ekstrak Etanol Daun Pepaya (Carica papaya) Terhadap Larva Aedes aegypti. Fakultas Kedokteran Universitas Riau.

30. Shepard, D. S., Undurraga, E. A., \& Halasa, Y. A. (2013). Economic and Disease Burden of Dengue in Southeast Asia. PLoS Neglected Tropical Diseases, 7(2), 1-12.

31. Temefos. Retrieved February 10, 2018, from https://pubchem.ncbi.nlm.nih.gov/compound/t emephos\#section=Top

32. Tyas, D.W., Wahyuni, D., \& Hariyadi, S. (2014). Perbedaan Toksisitas Ekstrak Rebusan dan Rendaman Daun Pepaya (Carica papaya L.) Terhadap Mortalitas Larva Nyamuk Aedes aegypti L. Pancaran, 3(1), 59-68.

33. Wahyuni, D. (2015). New Bioinsecticide Granules Toxin from Ectract of Papaya (Carica Papaya) Seed and Leaf Modified Against Aedes Aegypti Larvae. Procedia Environmental Sciences, 23, 323-328.

34. World Health Organization, Dengue. (2016, March 8). Retrieved December 2, 2017, from http://www.searo.who.int/topics/dengue/en/

35. Yogiraj, V., Goyal, P.K., Chauhan, C.S., Goyal, A., \& Vyas, B. (2014). Carica papaya Linn: An Overview. International Journal of Herbal Medicine, 2(5), 1-8.

36. Yunair, N., Majid, R. Ode, L., Zety, M., \& Wildan, E. (2017). Larvacidal effect of papaya leaf extracts (Carica papaya L.) toward the larvae of Anopheles aconitus donits mosquitoes as an effort to prevent malaria disease in Rural Areas of Southern Konawe. International Seminar on Global Health, 290-300. 